\title{
Relation between CYP2C19 phenotype and genotype in a group of Brazilian volunteers
}

\author{
Rafael Linden $^{1 *}$, Ana Luiza Ziulkoski ${ }^{1}$, Paula Tonello ${ }^{1}$, Maína Wingert ${ }^{1}$, André Arigony Souto ${ }^{2}$ \\ ${ }^{1}$ Institute of Health Sciences, Feevale University Center, \\ ${ }^{2}$ Institute of Chemistry, Pontifical Catholic University of Rio Grande do Sul
}

\begin{abstract}
The CYP2C19 gene presents polymorphism affecting the pharmacokinetics of several drugs of clinical importance. The purpose of this study was to investigate the correlation between CYP2C19 genotype and metabolic phenotype in a group of 38 Brazilian volunteers, evaluating the phenotype prediction capacity of the genotyping procedure. For CYP2C19 phenotyping, omeprazole was used as the probe drug, using the hydroxylation metabolic ratio as the phenotypic indicator. Venous blood samples were drawn before and three hours after an oral administration of $20 \mathrm{mg}$ omeprazole. The plasma concentrations of omeprazole and hydroxy-omeprazole were determined by high performance liquid chromatography. The genotyping assay was carried out using a Real-Time-PCR-based assay, identifying the alleles *1 (completely functional), $* 2, * 3$ and $* 4$ (null). The phenotyping procedure estimated the presence of 4 poor, 34 extensive and 1 ultra-extensive metabolizer. The genotyping identified 4 poor, 23 extensive and 11 intensive metabolizers. The groups of volunteers classified according to the number of active alleles of CYP2C19 had significant differences in the metabolic ratios of omeprazole hydroxylation. However, volunteers exhibiting the same number of active alleles presented different phenotypes. Therefore, the phenotyping of CYP2C19 is a more promising alternative to dose individualization of CYP2C19 substrate drugs.
\end{abstract}

Uniterms: Metabolic phenotyping. Metabolic genotyping. CYP2C19 gene.

O gene CYP2C19 apresenta polimorfismo genético, com impacto importante na farmacocinética de diversos fármacos de importância clínica. O objetivo deste estudo foi avaliar a correlação entre genótipo e fenótipo de CYP2C19 em um grupo de 38 voluntários brasileiros, avaliando a capacidade de predição do fenótipo a partir de testes de genotipagem. Para a fenotipagem, utilizou-se omeprazol (OME) como fármaco-sonda para CYP2C19, empregando sua razão metabólica de hidroxilação como indicador fenotípico. Amostras de sangue foram coletadas antes e três horas após a administração oral de $20 \mathrm{mg}$ do fármaco. As concentrações plasmáticas de OME e seu metabólito foram determinadas por cromatografia líquida de alta eficiência. A genotipagem de CYP2C19 foi realizada através de ensaio baseado na reação em cadeia da polimerase em tempo real, identificando os alelos *1 (completamente funcional), $* 2 \mathrm{e} * 3$ (nulos). Pela fenotipagem foi possível estimar a presença de 3 metabolizadores lentos, 34 rápidos e 1 ultra-rápido; enquanto pela genotipagem foi determinada a presença de 4 metabolizadores lentos, 23 rápidos e 11 intermediários. Os grupos de voluntários classificados de acordo com o número de alelos ativos apresentaram diferenças significativas entre as razões metabólicas de hidroxilação de omeprazol. Entretanto, indivíduos com o mesmo genótipo apresentaram fenótipos diferentes. Desta forma, a fenotipagem apresenta-se como alternativa mais promissora para a individualização das doses de fármacos substratos de $C Y P 2 C 19$.

Unitermos: Fenotipagem metabólica. Genotipagem metabólica. Gene CYP2C19

*Correspondence: R. Linden. Instituto de Ciências da Saúde, Centro Universitário Feevale, Rodovia RS-239, n 2755, 93352-000 - Novo Hamburgo - RS, Brasil. E-mail: rafael.linden@feevale.br 


\section{INTRODUCTION}

Drug kinetics presents considerably variation among individuals and a part of this variation can be credited to differences in expression and activity of cytochrome P450 system (CYP). Among the clinically relevant CYP genes, CYP2C19 has particular importance.

CYP2C19 gene presents genetic polymorphism, with significant effects on the disposition of several important drugs as amitriptyline, nortriptyline, diazepam, imipramine, propranolol and selective serotonine reuptake inhibitors (Linden, 2006). Besides the presence of the completely functional allele CYP $2 C 19 * 1$, the individual variability of CYP2C19 activity is associated to the presence of the null alleles $C Y P 2 C 19 * 2$ and $C Y P 2 C 19 * 3$, which has been described as responsible for about $87 \%$ of all poor metabolizers (PM) in Caucasian populations and $100 \%$ in Asians (Morais et al., 1994; Goldstein et al.,1997). Also, another alleles related to absence of CYP2C19 activity in vivo has been described, as CYP2C19*4, CYP2C19*5, $C Y P 2 C 19 * 6, C Y P 2 C 19 * 7$ and CYP2C19*8 (Human Cytochrome P450 allele Nomenclature Committee, 2008). Recently, Sim and coworkers (2006) identified the CYP 2 C19*17 allele that is associated to increased activity of the CYP2C19 enzyme.

One of the major objectives of clinical pharmacogenetics is the prediction of the individual metabolic activity, allowing proper dose adjustment. Then, individuals with reduced metabolic activity could receive lower drug doses, minimizing potential adverse effects, while patients with increased activity could receive higher doses, increasing the probability of a successful treatment. This prediction can be performed by genotyping of $C Y P$ and other genes related to drug metabolism, or alternatively trough the phenotyping of the enzymes by the administration of probe drugs. Probe drugs are substances whose metabolism is well known, being metabolized mainly by the studied enzyme, and the rate of metabolite formation is used to evaluate the metabolic activity (Linden, Souto, 2005).

CYP2C19 phenotyping is usually performed using omeprazole as probe drug, once the conversion of omeprazole (OME) to hydroxy-omeprazole (HOME) is mainly catalyzed by this enzyme, while the conversion of OME to omeprazole-sulphone (OMES) is dependent of CYP3A4 activity (Figure 1) (Streetman et al., 2000). The phenotypes are classified using metabolic ratios of OME hydroxylation, calculated with OME and HOME plasma concentrations 3 hours after a single oral administration of $20 \mathrm{mg}$ OME (Linden et al., 2007). This indicator is named metabolic ratio (MR) and usually presents a normal distribution on tested populations (Tamminga et al., 2001). MR values below 0.12 are found in ultra-extensive metabolizers (UE) and above 4.0 in poor metabolizers (PM), being classified as extensive metabolizers (EM) the individuals with intermediate values (González et al., 2003).

Before the incorporation of CYP2C19 genotyping to clinical practice, its phenotyping prediction capability must be validated. Some recent works have shown a correlation between the MR of CYP2C19 with the genotype, but it is well known that the phenotype is affected by environmental and individual factors that cannot be predicted by genotyping procedures. As an example, previous studies have proposed tricyclic antidepressant dose adjustments based on CYP2C19 genotyping, with smaller doses recommended to PM patients (Kirchheiner et al., 2001; Kirchheiner et al., 2003). It must be pointed<smiles>COc1ccc2[nH]c([SH](C)(=O)Cc3ncc(C)cc3C)nc2c1</smiles>

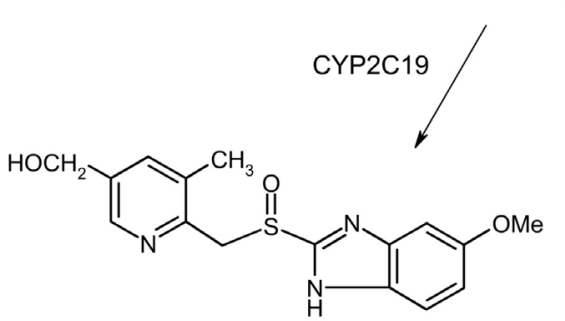

5-hydroxy-omeprazole

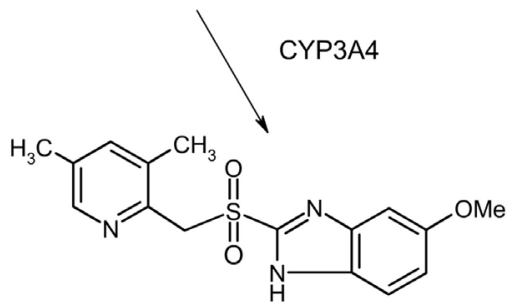

Omeprazole sulphone

FIGURE 1 - Main metabolic routes of omeprazole. CYP2C19 catalyzes omeprazole hydroxylation forming 5-hydroxy-omeprazole, while CYP3A4 catalyzes the sulphonation reaction, leading to omeprazole-sulphone. 
out that the clinical application of these recommendations requires that to each determined genotype, a phenotype may be predicted with accuracy.

Considering the inexistence of correlation studies among CYP2C19 genotype and phenotype in Brazilian population, the objective of this work was to evaluate the genotype-phenotype relation of this enzyme in a group of Brazilian volunteers, in order to know the phenotype predictive capability of the genotyping tests.

\section{MATERIALS AND METHODS}

\section{Volunteer selection and sample collection}

The sampling protocol was approved by the Ethics Research Committee of Feevale University Center and an informed consent was signed by all volunteers participating in the study. A group of 38 Caucasian volunteers ( 30 women and 8 men) participated in the study, all with age above 18 , without history of liver or kidney disease, without history of hypersensitivity to drugs and that did not use any drug or herbal preparation two weeks before the collection of the samples. Main biodemographic data of the volunteers were: mean weight of $64.3 \mathrm{~kg}$ (range 51 to $93 \mathrm{~kg}$ ), mean body mass index of 23.1 (range 19.9 to 31.1 ) and mean age of 27.4 years (range 21 to 43 ). 15 female volunteers used oral hormonal contraceptives during the study. The volunteers were oriented to remain fasted 8 hours before sample collection. Venous blood samples were collected in vacuum tubes containing EDTA, either before and after the administration of the probe drug omeprazole. The sample collected before OME administration was used for genotyping.

\section{Determination of omeprazole and hydroxy- omeprazole plasma levels}

Plasma concentrations of OME and HOME were determined by high-performance liquid chromatography (HPLC), as described by Linden et al. (2007). Briefly, to a $1 \mathrm{~mL}$ plasma sample, Tris buffer $\mathrm{pH} 9.5$ and internal standard sulpiride (IS) were added, followed by ethyl acetate extraction. After solvent evaporation, OME, HOME and IS were separated using a Shim-Pack RP-18e column (150 x $4.6 \mathrm{~mm}$, p.d. $5 \mu \mathrm{m}$ ), with a phosphate buffer $\mathrm{pH}$ 7.6-acetonitrile $(24: 76, \mathrm{v} / \mathrm{v})$ mobile phase. Flow rate was $1 \mathrm{~mL} / \mathrm{min}$ and total run time was $15 \mathrm{~min}$. Mean retention times were $2.7 \mathrm{~min}$ for IS, $4.1 \mathrm{~min}$ for HOME and $11.6 \mathrm{~min}$ for OME. Detection (UV at $302 \mathrm{~nm}$ ) was linear in the range of 25 to $1000 \mathrm{ng} / \mathrm{mL}$. The method has acceptable precision and accuracy, with a quantification limit of $25 \mathrm{ng} / \mathrm{mL}$ for both analytes. The chromatographic equipment was acquired from Shimadzu (Kyoto, Japan).

\section{CYP2C19 phenotyping}

The volunteers received single oral doses of $20 \mathrm{mg}$ OME, together with $200 \mathrm{~mL}$ of water. Venous blood samples were drawn 3 hours after administration. Immediately after collection, samples were centrifuged at 2,000 g and plasma was transferred to polypropylene microtubes and stored at $-20{ }^{\circ} \mathrm{C}$ until chromatographic analysis. The hydroxylation metabolic ratios were calculated using the values of $\mathrm{OME}$ and $\mathrm{HOME}$ concentration, and were defined as $[\mathrm{OME}] /[\mathrm{HOME}]$. Individuals with MR higher than 4.0 were classified as PM, with MR lower than 0.12 were classified as UE and the group with intermediate values were classified as EM (González et al., 2003). The MR of the groups PM, UE and EM were compared by KruskalWallis test, with $P=0.001$. SPSS version 11.5 was used for statistical calculations.

\section{CYP2C19 genotyping}

CYP2C19 genotyping was performed by a realtime polymerase chain reaction assay (TaqMan ${ }^{\circledR}$ C_1329163_10, Applied Biosystems), according to the manufacturer's instructions. The genotyping procedure was able to identify the alleles $C Y P 2 C 19 * 1, * 2 \mathrm{e} * 3$. For the determination of the number of active alleles, the *1 allele was considered active and the alleles $* 2$ e $* 3$ were considered as inactive. Therefore, individuals with none active alleles were classified as PMg (genotypic poor metabolizer); individuals with 1 active allele were classified as IMg (genotypic intermediate metabolizer) and individuals with 2 active alleles were classified as EMg (genotypic extensive metabolizer).

\section{RESULTS AND DISCUSSION}

Table I presents the phenotypes predicted by the MR [OME]/[HOME] and by the genotyping for the 38 volunteers. The phenotyping procedure allowed the identification of 4 PM (10.5\%), 33 EM (87\%) e 1 UE (2.5 $\%)$. Alternatively, the genotyping identified $4 \mathrm{PMg}(10.5$ $\%), 23 \mathrm{EMg}(60.5 \%)$ and $11 \mathrm{IMg}(29 \%)$. The frequencies of genotype-predicted phenotypes were similar to those found in previous studies with Caucasian populations (Goldstein et al., 1997; Sachse et al., 1997), although Xie et al. (1999) described a frequency of CYP2C19 PMg in the order of $2.8 \%$. Naturally, the limited sample size of the 
present study limits the comparison with wider previous investigations.

The groups classified on their number of active alleles presented significant differences between the omeprazole hydroxylation metabolic ratios, the CYP2C19 phenotypic indicator employed on this study, as presented in Table 2. Nevertheless, a clear superposition between $[\mathrm{OME}] /[\mathrm{HOME}]$ values of the groups of number of active alleles was verified, with wider value dispersion in the PMg group (Figure 2, Table II). Probably, this superposition is related to the variability of alternative metabolic routes, especially by the biotransformation of omeprazole to omeprazole-sulphone catalyzed by CYP3A4 (Andersson et al., 1994).

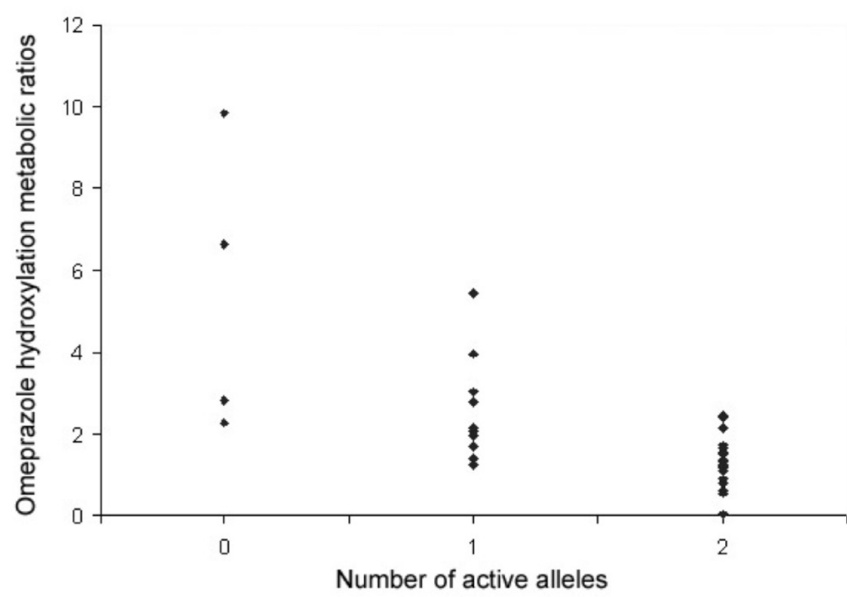

FIGURE 2 - Dispersion of omeprazole hydroxylation metabolic ratios with respect to the number of $C Y P 2 C 19$ active alleles.

Previous studies had determined threshold values for the classification of the PM and EM groups based on the calculation of antimodes of the normal distribution of MR. Considering that the small sampling size of the present study did not allow the calculation of antimodes, the use of previously determined values for CYP2C19 phenotype classification based on omeprazole hydroxylation metabolic ratios (González et al., 2003) allowed the estimate of the presence of 1 UE (2.6\%), 3 PM (7.9\%) e $34 \mathrm{EM}(89.5 \%)$ in the group of volunteers.

During the development of this study, a genetic test for identification of the CYP2C19*17 allele, the only currently known that codifies a CYP2C19 isoform with increased activity, was not available. Taking into consideration the lack of reports of CYP2C19 induction by another drugs or environmental factors, it is probable that the presence of an UE volunteer among the volunteers could be due to presence of the $* 17$ allele. Indeed, Sim and coworkers
(2006) concluded that CYP2C19*17 homozygote individuals can present omeprazole area under the curve about 35 to $40 \%$ smaller than $C Y P 2 C 19 * 1$ homozygote, after the administration of single oral doses.

Considering that individuals with 1 CYP2C19 functional allele usually have a EM phenotype, the number of PM and EM estimated either by phenotyping and genotyping are very similar. However, the genotyping did not allow the identification of 1 phenotypic UE in the group, considering that the genotyping procedure screened only the *1, $* 2$ and $* 3$ alleles. Also, one individual PMg had an omeprazole hydroxylation metabolic ratio compatible with the EM phenotype, as well as 2 individuals IMg presented a PM phenotype. Therefore, the genotyping procedure at the PMg group did not allowed an adequate prediction of the omeprazole hydroxylation activity of all participants of the study.

The results showed that, from a population view, there are statistically significant differences in the metabolic activity of CYP2C19 among groups with different number of active alleles. However, in an individual basis, the CYP2C19 genotype cannot always predict accurately the metabolic activity. Phenotyping procedures using a probe drug as omeprazole allow the characterization of CYP2C19 activity at the moment of the test, being a more accurate measure of the extent of drug metabolism. Naturally, CYP2C19 activity is affected by a sort of environmental and individual factors, and the realization of phenotyping procedures every time a substrate of this enzyme is prescribed is unrealistic in clinical practice. Another alternative is the use of metabolic ratios obtained at routine therapeutic drug monitoring analyses, when the correlation of these rations and the phenotype of CYP2C19 are well known (Van der Weide et al., 2005). Recent studies demonstrated the correlation of CYP2C19 phenotype with amitriptyline demethylation metabolic ratios, a reaction also catalyzed by CYP2C19 (Linden et al., 2008).

\section{CONCLUSIONS}

Groups of volunteers classified according to their number of CYP2C19 active alleles as PMg, IMg and EMg had significant differences on their omeprazole hydroxylation metabolic ratios. However, there was considerable variation on the metabolic ratios within groups, with 2 $\mathrm{PMg}$ being classified as EM by phenotyping. Also, $2 \mathrm{IMg}$ presented PM phenotype. CYP2C19 genotype did not present complete concordance with phenotypes. CYP2C19 phenotyping is a promising tool to drug dose individualization, once allow the determination of the metabolic activity at the desired moment. 
TABLE I - CYP2C19 phenotyping and genotyping data of volunteers

\begin{tabular}{|c|c|c|c|c|c|c|}
\hline Volunteer & Gender & $\begin{array}{l}{[\mathrm{OME}] /} \\
{[\mathrm{HOME}]}\end{array}$ & Phenotype & $\begin{array}{l}\text { Present } \\
\text { alleles }\end{array}$ & $\begin{array}{c}\text { Number of active } \\
\text { alleles }\end{array}$ & $\begin{array}{l}\text { Genotype-predicted } \\
\text { phenotype }\end{array}$ \\
\hline 1 & $\mathrm{M}$ & 0.05 & UE & $* 1 / * 1$ & 2 & $\mathrm{EMg}$ \\
\hline 2 & $\mathrm{~F}$ & 0.54 & EM & $* 1 / * 1$ & 2 & EMg \\
\hline 3 & $\mathrm{~F}$ & 0.61 & EM & $* 1 / * 1$ & 2 & $\mathrm{EMg}$ \\
\hline 4 & $\mathrm{~F}$ & 0.80 & EM & $* 1 / * 1$ & 2 & EMg \\
\hline 5 & $\mathrm{~F}$ & 0.80 & EM & $* 1 / * 1$ & 2 & EMg \\
\hline 6 & M & 0.90 & EM & $* 1 / * 1$ & 2 & EMg \\
\hline 7 & $\mathrm{~F}$ & 0.90 & EM & $* 1 / * 1$ & 2 & $\mathrm{EMg}$ \\
\hline 8 & $\mathrm{~F}$ & 1.10 & EM & $* 1 / * 1$ & 2 & EMg \\
\hline 9 & $\mathrm{~F}$ & 1.17 & EM & $* 1 / * 1$ & 2 & EMg \\
\hline 10 & $\mathrm{~F}$ & 1.22 & EM & $* 1 / * 1$ & 2 & $\mathrm{EMg}$ \\
\hline 11 & $\mathrm{~F}$ & 1.24 & EM & $* 1 / * 1$ & 2 & EMg \\
\hline 12 & M & 1.24 & EM & $* 1 / * 1$ & 2 & EMg \\
\hline 13 & $\mathrm{~F}$ & 1.25 & EM & $* 1 / * 2$ & 1 & $\mathrm{IMg}$ \\
\hline 14 & M & 1.25 & EM & $* 1 / * 1$ & 2 & EMg \\
\hline 15 & $\mathrm{M}$ & 1.30 & EM & $* 1 / * 1$ & 2 & EMg \\
\hline 16 & $\mathrm{~F}$ & 1.34 & EM & $* 1 / * 1$ & 2 & $\mathrm{EMg}$ \\
\hline 17 & F & 1.40 & EM & $* 1 / * 2$ & 1 & $\mathrm{IMg}$ \\
\hline 18 & $\mathrm{~F}$ & 1.51 & EM & $* 1 / * 1$ & 2 & $\mathrm{EMg}$ \\
\hline 19 & $\mathrm{M}$ & 1.55 & EM & $* 1 / * 1$ & 2 & EMg \\
\hline 20 & $\mathrm{~F}$ & 1.64 & EM & $* 1 / * 1$ & 2 & EMg \\
\hline 21 & M & 1.65 & EM & $* 1 / * 1$ & 2 & EMg \\
\hline 22 & $\mathrm{~F}$ & 1.69 & EM & $* 1 / * 2$ & 1 & $\mathrm{IMg}$ \\
\hline 23 & F & 1.70 & EM & $* 1 / * 2$ & 1 & $\mathrm{IMg}$ \\
\hline 24 & F & 1.72 & EM & $* 1 / * 1$ & 2 & $\mathrm{EMg}$ \\
\hline 25 & $\mathrm{~F}$ & 1.97 & EM & $* 1 / * 2$ & 1 & $\mathrm{IMg}$ \\
\hline 26 & $\mathrm{M}$ & 2.06 & EM & $* 1 / * 2$ & 1 & $\mathrm{IMg}$ \\
\hline 27 & $\mathrm{~F}$ & 2.12 & EM & $* 1 / * 1$ & 2 & $\mathrm{EMg}$ \\
\hline 28 & $\mathrm{~F}$ & 2.12 & EM & $* 1 / * 2$ & 1 & $\mathrm{IMg}$ \\
\hline 29 & F & 2.27 & EM & $* 2 / * 2$ & 0 & $\mathrm{PMg}$ \\
\hline 30 & $\mathrm{~F}$ & 2.41 & EM & $* 1 / * 1$ & 2 & EMg \\
\hline 31 & F & 2.45 & EM & $* 1 / * 1$ & 2 & $\mathrm{EMg}$ \\
\hline 32 & F & 2.77 & EM & $* 1 / * 2$ & 1 & $\mathrm{IMg}$ \\
\hline 33 & F & 2.83 & EM & $* 2 / * 2$ & 0 & $\mathrm{PMg}$ \\
\hline 34 & $\mathrm{~F}$ & 3.03 & EM & $* 1 / * 2$ & 1 & $\mathrm{IMg}$ \\
\hline 35 & F & 3.97 & $\mathrm{PM}$ & $* 1 / * 2$ & 1 & $\mathrm{IMg}$ \\
\hline 36 & F & 5.44 & PM & $* 1 / * 2$ & 1 & $\mathrm{IMg}$ \\
\hline 37 & F & 6.62 & PM & $* 2 / * 2$ & 0 & $\mathrm{PMg}$ \\
\hline 38 & $\mathrm{~F}$ & 9.83 & $\mathrm{PM}$ & $* 2 / * 2$ & 0 & $\mathrm{PMg}$ \\
\hline
\end{tabular}

OME, omeprazole; HOME, hydroxy-omeprazole; M, male; F, female; UE, ultra-extensive metabolizer; EM, extensive metabolizer; PM, poor metabolizer; IM, intermediate metabolizer. 
TABLE II - Comparison between the number of active alleles of CYP2C19 and hydroxylation metabolic ratios of omeprazole

\begin{tabular}{lccc}
\hline Number of active alleles & $\mathrm{n}$ & {$[\mathrm{OME}] /[\mathrm{HOME}] \pm \mathrm{SD}(\min -\max )^{*}$} & Genotype-predicted phenotype \\
\hline 2 & 23 & $1.28 \pm 0.57(0.05-2.45)$ & $\mathrm{EMg}$ \\
1 & 11 & $2.49 \pm 1.26(1.25-5.44)$ & $\mathrm{IMg}$ \\
0 & 4 & $5.39 \pm 3.54(2.27-9.83)$ & $\mathrm{PMg}$ \\
\hline
\end{tabular}

* statistically significant difference among groups, $\mathrm{P}=0.001$, Kruskal-Wallis test

\section{ACKNOWLEDGEMENTS}

To Feevale University Center, for financial support. To Dr. Mladen Tzvetkov, Department of Clinical Pharmacology of the Georg-August Universitäet Göettingen, Germany, for providing the genotyping analysis.

\section{REFERENCES}

ANDERSSON, T.; MINERS, J. O.; VERONESE, M. E.; BIRKETT, D. J. Identification of liver cytochrome P450 isoforms mediating secondary omeprazole metabolism. $\mathrm{Br}$. J. Clin. Pharmacol., v.37, p.597-604, 1994.

DE MORAIS, S. M. F.; WIKINSON, G. R.; BLAISDELL, J.; MEYER, U. A.; NAKAMURA, K.; GOLDSTEIN, J.A. The major genetic defect responsible for the polymorphism of S-mephenytoin metabolism in humans. J. Biol. Chem., v.269, p.15419-15422, 1994.

GOLDSTEIN, J.A.; ISHIZAKI, T.; CHIBA, K.; DE MORAIS, S. M. F.; BELL, D.; KRAHN, P. M.; EVANS, D. A. P. Frequencies of defective CYP2C19 alleles responsible for mephenytoin poor metabolizer phenotype in various Oriental, Caucasian, Saudi Arabian and American black populations. Pharmacogenetics, v.7, p.59-64, 1997.

GONZÁLEZ, H. M.; ROMERO, E. M.; PEREGRINA, A. A.; CHAVEZ, T. J.; ESCOBAR-ISLAS, E.; LOZANO, F.; HOYO-VADILLO, C. CYP2C19 and CYP3A4 dependent omeprazole metabolism in west mexicans. J. Clin. Pharmacol., v.43, p.1211-1215, 2003.

\section{HUMAN CYTOCHROME P450 ALLELE NOMENCLATURE} COMMITTEE. CYP2C19 Allele Nomenclature. Available at: <http://www.cypalleles.ki.se/cyp2c19.htm>. Acessed on: 10 aug. 2008.

LINDEN, R.; SOUTO, A. A. Fenotipagem de enzimas metabolizadoras polimórficas e monitoramento terapêutico como uma ferramenta na farmacologia clínica dos antidepressivos tricíclicos, uma revisão. Rev. Bras. Toxicol., v.18, p.131-142, 2005.
LINDEN, R. Análise toxicológica sistemática e fenotipagem de CYP2C19: contribuição ao monitoramento terapêutico da amitriptilina. Porto Alegre, 2006, 148 p. [Tese de Doutorado. Faculdade de Biociências. Pontifícia Universidade Católica do Rio Grande do Sul].

LINDEN, R.; ZIULKOSKI, A. L.; WINGERT, M.; TONELLO, P.; SOUTO, A. A. Simultaneous determination of omeprazole, hydroxyomeprazole and omeprazole sulphone in human plasma by isocratic HPLC-DAD: application to the phenotyping of CYP2C19 and CYP3A4 in Brazilian volunteers. J. Braz. Chem. Soc., v.18, p.733-740, 2007.

LINDEN, R.; ANTUNES, M. V.; ZIULKOSKI, A. L.; WINGERT, M.; TONELLO, P.; TZVETKOV, M. ; SOUTO, A. A. Determination of amitriptyline and its main metabolites in human plasma samples using HPLC-DAD: application to the determination of metabolic ratios after single oral dose of amitriptyline. J. Braz. Chem. Soc., v.19, p. $35-41,2008$

KIRCHHEINER, J.; BROSEN, K.; DAHL, M. L.; GRAM, L.F.; KASPER, S.; ROOTS, I.; SJÖQVIST, F.; SPINA, E.; BROCKMÖLLER, J. CYP2D6 and CYP2C19 genotypebased dose recommendations for antidepressants, a first step towards subpopulation-specific dosages. Acta Psychiatr. Scand., v.104, p.173-192, 2001.

KIRCHHEINER, J.; BERTILSSON, L.; BRUUS, H.; WOLF, A.; ROOTS, I.; BAUER, M. Individualized Medicine - Implementation of Pharmacogenetic Diagnostics in Antidepressant Drug Treatment of Major Depressive Disorders. Pharmacopsychiatry, v.36, p.s235-s243, 2003.

SACHSE, C.; BROCKMÖLLER, J.; BAUER, S.; ROOTS, I. Cytochrome P450 2D6 variants in a Caucasian population, allele frequencies and phenotypic consequences. Am. $J$. Hum. Genet., v.60, p.284-295,1997. 
SIM, S. C.; RISINGER, C.; DAHL, M. L.; AKLILLU, E.; CHRISTENSEN, M.; BETTILSSON, L.; INGELMANSUNDBERG, M. A common novel CYP2C19 gene variant causes ultrarapid drug metabolism relevant for the drug response to proton pump inhibitors and antidepressants. Clin. Pharmacol. Ther., v.79, p.103-113, 2006.

STEIMER, W.; ZÖPF, K.; VONAMELUNXEN, S.; PFEIFFER, H.; BACHOFER, J.; POPP, J.; MESSNER, B.; KISSLING, W.; LEUCHT, S. Allele-specific change of concentration and functional gene dose for the prediction of steady-state serum concentrations of amitriptyline and nortriptyline in CYP2C19 and CYP2D6 extensive and intermediate metabolizers. Clin. Chem., v.50, p.1623-1633, 2004.

STREETMAN, D. S.; BERTINO, J. S.; NAFZIGER, A. N. Phenotyping of drug-metabolizing enzymes in adults, a review of in-vivo Cytochrome $\mathrm{P} 450$ phenotyping probes. Pharmacogenetics, v.10, p.187-216, 2000.
TAMMINGA, W. J.; WEMER, J.; OOSTERHUIS, B.; BRAKENHOFF, J. P. G.; GERRITS, M. G. F.; DE ZEEUW, R, A.; DE LEIJ, L. F. M. H.; JONKMAN, J. H. G. An optimized methodology for combined phenotyping and genotyping on CYP2D6 and CYP2C19. Eur. J. Clin. Pharmacol., v.57, p.143-146, 2001.

VAN DE WEIDE, J.; VAN BAALEN-BENEDEK, E. H.; KOOSTRA-ROS, J. E. Metabolic ratios of psychotropics as indication of Cytochrome P450 2D6/2C19 genotype. Ther. Drug Monit., v.27, p.478-483, 2005.

XIE, H. G.; STEIN, C. M.; KIM, R. B.; WILKINSON, G. R.; FLOCKHART, D. A.; WOOD, A. J. Allelic, genotypic and phenotypic distributions of S-mephenytoin 4'-hydroxylase (CYP2C19) in healthy Caucasian populations of European descent throughout the world. Pharmacogenetics, v.9, p.539-549, 1999.

Received for publication on $14^{\text {th }}$ April 2008 Accepted for publication on $20^{\text {th }}$ January 2009 